\title{
Muscular system in the interna of Polyascus polygenea and Sacculina pilosella (Cirripedia: Rhizocephala: Sacculinidae)
}

\author{
A.A. Miroliubov ${ }^{1,3}$, I.E. Borisenko², M.A. Nesterenko ${ }^{3}$, O.M. Korn ${ }^{4}$, \\ A.D. Lianguzova ${ }^{3}$, S.A. Ilyutkin ${ }^{3}$, N.E. Lapshin ${ }^{3}$, A.A. Dobrovolskij ${ }^{3}$ \\ ${ }^{1}$ Zoological Institute RAS, Universitetskaya emb., 1, Saint-Petersburg, 199034, Russia. \\ E-mail: alexmiroliubov@gmail.com \\ ${ }^{2}$ Saint-Petersburg State University, Department of Embryology, Universitetskaya emb., 7/9, Saint \\ Petersburg, 199034, Russia. \\ ${ }^{3}$ Saint-Petersburg State University, Department of Invertebrate Zoology, Universitetskaya emb., 7/ \\ 9, Saint Petersburg, 199034, Russia. \\ ${ }^{4}$ National Scientific Center of Marine Biology, FEB RAS, Palchavskogo str., 17, Vladivostok \\ 690041, Russia.
}

\begin{abstract}
Rhizocephala is a group of unique and highly specialized parasitic crustaceans. Due to specialization in endoparasitism adult rhizocephalans have lost almost all the traits of free-living crustaceans. Despite large amount of data on different aspects of their biology there is still insufficient knowledge of their interna morphology. The muscular system in interna has been found and described only for Peltogaster paguri from the family Peltogastridae. The aim of our study is to visualize and describe muscular system in the interna of Polyascus polygenea and Sacculina pilosella (family Sacculinidae). Representatives of both species have similar type of muscular system, which is significantly different from that in $P$. paguri. The muscular system of the sacculinids consists of muscular rosettes located within the body wall of each rootlet. Muscle fibers in these rosettes are oriented in different directions. Tiny muscular processes connect the rosettes to each other. These contractile elements form a joint net-like muscular system. We suggest that this muscular system provides peristaltic movement of the roots and transports nutrients within the interna.

How to cite this article: Miroliubov A.A., Borisenko I.E., Nesterenko M.A., Korn O.M., Lianguzova A.D., Ilyutkin S.A., Lapshin N.E. , Dobrovolskij A.A. 2019. Muscular system in the interna of Polyascus polygenea and Sacculina pilosella (Cirripedia: Rhizocephala: Sacculinidae) // Invert. Zool. Vol.16. No.1. P.48-56. doi: 10.15298/invertzool.16.1.06
\end{abstract}

KEY WORDS: Rhizocephala, muscular system, Sacculinidae, interna. 


\title{
Мышечная система интерны Polyascus polygenea и Sacculina pilosella (Rhizocephala: Sacculinidae)
}

\author{
А.А. Миролюбов ${ }^{1,3}$, И.Е. Борисенко ${ }^{2}$, М.А. Нестеренко ${ }^{3}$, \\ О.М. Корн ${ }^{4}$, А.Д. Лянгузова ${ }^{3}$, С.А. Илюткин ${ }^{3}$, Н.Е. Лапшин ${ }^{3}$, \\ А.А. Добровольский ${ }^{3}$
}

\footnotetext{
1 Зоологический институт РАН, Университетская наб. 1, Санкт-Петербург, 199034, Росcия. E-mail: alexmiroliubov@gmail.com

${ }^{2}$ Санкт-Петербургский государственный университет, Кафедра эмбриологии, Университетская наб. 7/9, Санкт-Петербург, 199034, Россия.

${ }^{3}$ Санкт-Петербургский государственный университет, Кафедра зоологии беспозвоночных, Университетская наб. 7/9, Санкт-Петербург, 199034, Россия.

${ }^{4}$ Национальный научный центр морской биологии им. А.В. Жирмунского ДВО РАН, Лаборатория эмбриологии, ул. Пальчевского, д. 17, г. Владивосток, 690041, Россия.
}

PЕЗЮМЕ: Rhizocephala — группа высоко специализированных паразитических ракообразных. В ходе адаптаций к эндопаразитизму взрослые представители корнеголовых утратили почти все черты свободноживущих родственников. Несмотря на большой объем данных о разных аспектах биологии этих животных, все еще остаются белые пятна в знаниях, касающихся морфологии интерны. Мышечная система интерны всего однажды была описана у представителей вида Peltogaster paguri из сем. Peltogastridae. Поэтому мы поставили цель визуализировать и описать мышечную систему в интерне Polyascus polygenea и Sacculina pilosella (сем. Sacculinidae). Мышечная система у обоих видов имеет схожее строение, которое, при этом, заметно отличается от строения мышечной системы $P$. paguri. Мышечная система представителей сем. Sacculinidae состоит из звездообразных мышечных элементов, располагающихся в стенке каждого столона. В состав каждого звездообразного мышечного элемента входят мышечные волокна, организованные в разных направлениях. Соседние мышечные элементы соединены между собой тонкими мышечными фибриллами. Таким образом, мышечные элементы формируют общую мышечную систему. Мы предполагаем, что подобная мышечная система обеспечивает перистальтические сокращения столонов и, таким образом, осуществляется транспорт питательных веществ по всей интерне.

Как цитировать эту статью: Miroliubov A.A., Borisenko I.E., Nesterenko M.A., Korn O.M., Lianguzova A.D., Ilyutkin S.A., Lapshin N.E., Dobrovolskij A.A. 2019. Muscular system in the interna of Polyascus polygenea and Sacculina pilosella (Cirripedia: Rhizocephala: Sacculinidae) // Invert. Zool. Vol.16. No.1. P.48-56. doi: 10.15298/ invertzool.16.1.06

КЛЮЧЕВЫЕ СЛОВА: Rhizocephala, мышечная система, Sacculinidae, интерна. 


\section{Introduction}

Parasitic crustaceans from the order Rhizocephala have highly modified life cycle (Glenner, 2001; Pérez-Losada et al., 2002; Høeg, Rybakov, 2007; Høeg et al., 2012), unique ontogeny and newly formed adult body (Glenner, Høeg, 1995; Glenner et al., 2000; Korn et al., 2000; Korn, Rybakov, 2001). Due to deep specialization in endoparasitism the adult rhizocephalans have lost almost all the traits of freeliving crustaceans (Høeg et al., 2005). The body of an adult female consists of two parts: interna and externa. The interna is a system of ramifying hollow rootlets, and it is usually assumed to perform a trophic function. The externa is a temporarily formed structure containing the female's reproductive system (Høeg, 1995; Bresciani, Høeg, 2001). Nowadays there are numerous papers on the phylogeny, development, evolution, parasite-host interactions, and others aspects of the rhizocephalan biology (Alvarez et al., 1995, 2002; Høeg, 1995; Bresciani, Høeg, 2001; Graham, 2001; Bortolini, Alvarez, 2008; Kristensen et al., 2012; Belgrad, Griffen, 2015; Nagler et al., 2017; Pérez-Miguel, 2017; Lützen et al., 2018; Zacher, 2018). However, morphology of interna is still poorly described, especially in the terms of the muscular system. It has been shown that the representatives of Peltogaster paguri (Rathke, 1842) (fam. Peltogastridae) had striated muscular fibers in the wall of the main trunk. These fibres were organized in an unidirectional right spiral that braids the central lumen of the main trunk. The muscular system was heterogeneous along the main trunk. The density of muscular fibres was lower in the distal part of the main trunk than in its central part. It is supposed that this muscular arrangement provides peristaltic movements of the main trunk and is necessary for transport of nutrients along the interna (Miroliubov, 2017). Bresciani \& Høeg (Bresciani, Høeg, 2001) found muscle elements in the interna of Sacculina carcini (Thompson, 1836). They noticed a weak sinuous movement of living rootlets. Ultrastructural study of the interna revealed the presence of the muscular fibers (Bresciani, Høeg, 2001).
Unfortunately, the spatial organization of muscular system in the family Sacculinidae has never been described. Therefore in this study we focus on the muscular system of two species from the family Sacculinidae: Polyascus polygenea (Lützen, Takahashi, 1997) and Sacculina pilosella (Van Kampen, Boschma, 1925). Representatives of the family Sacculinidae have another type of the interna organization in contrast to the family Peltogastridae (Isaeva, 2001; Shukalyuk et al., 2001; Lützen, 2002; Shukalyuk, 2002; Miroliubov, 2017). It has no central elements, such as the main trunk in P. paguri; all the rootlets ramify randomly and infiltrate the whole body of the host. Thus follow another type of interna gross morphology we expect to find different organization of the muscular system.

\section{Methods}

\section{Animals}

The crabs Hemigrapsus sanguineus (De Haan, 1835) infected by Polyascus polygenea (Lützen, Takahashi, 1997) and crabs Pugettia quadridens (De Haan, 1839) infected by Sacculina pilosella (Van Kampen, Boschma, 1925) were collected during the summer 2018 in the Sea of Japan (Marine Biological Station "Vostok" of National Scientific Center of Marine Biology, FEB RAS) (N: 42.893720, E: 132.732755).

Infected crabs were dissected and parts of the interna were taken from the hosts' bodies.

\section{Immunocytochemistry (ICC)}

For immunocytochemical visualization of interna, samples were fixed in 4\% paraformaldehyde (PFA; Sigma-Aldrich) in phosphatebuffered saline (PBS; Fluka) at $4{ }^{\circ} \mathrm{C}$ overnight. Before immunocytochemical staining, the fixed material was rinsed several times during 24 hours with PBT (PBS + $0.1 \%$ Triton-X100; Sigma-Aldrich). During the next $24 \mathrm{~h}$ the specimens were incubated in TRITC-labeled phalloidin solution $(200 \mathrm{ng} / \mathrm{ml})$. After the material was rinsed three times for $10 \mathrm{~min}$ in PBS, it was stained with the DAPI nuclei stain $(1 \mathrm{ug} / \mathrm{ml}$; 
Sigma) in PBS for 1 hour, rinsed with PBS and mounted in DABCO-glycerol. Specimens were examined using the confocal laser scanning microscope Leica TCS SPE in Resource Centre "Microscopy and Microanalysis" of Research park of Saint-Petersburg State University. The images were processed by ImageJ software (FiJi).

Specimens for cryosectioning were rinsed several times during 24 hours with PBT, then incubated for 24 hours in $30 \%$ sucrose solution for cryoprotection. Sections $(40 \mu \mathrm{m})$ were made by cryotome Leica CM3050S. Following that, we used the described above protocol for immunocytochemical visualization.

Transmission and scanning electron microscopy (TEM)

For transmission electron microscopy, the samples were fixed overnight at $4{ }^{\circ} \mathrm{C}$ in $2.5 \%$ glutaraldehyde in phosphate buffer saline with addition of Sucrose (pH 7.4; $750 \mathrm{mOsM}$ ), and postfixed in $1 \% \mathrm{OsO}_{4}$ in the same buffer ( 1 hour at room temperature). After washing with the same buffer, the specimens were dehydrated through an ethanol series and acetone, and embedded in Epon-812 embedding media (Fluka). Semithin $(1 \mu \mathrm{m}$ thick $)$ and ultra-thin $(60-80 \mathrm{~nm})$ sections were cut with a Leica EM UC7 ultratome. Semi-thin sections were stained with a methylene blue and studied under Leica DM2500 microscope. Ultra-thin sections were stained with uranyl acetate followed by lead nitrate and examined with transmission electron microscope JEOL JEM 1400 in the Resource Centre "Chromas" and "Molecular and Cell Technologies" of the Research park of Saint-Petersburg State University.

\section{Results}

The interna of $P$. polygenea had numerous star-like muscular rosettes in the body wall of all examined rootlets (Fig. 1A). These contractile elements have muscular fibers lying in different directions (Fig. 1C, D). It is not clear if these contractile rosettes are multi or unicellular. All observed muscular fibers are striated (Fig. 1B).
Tiny muscular processes connect the adjacent muscular rosettes (Fig. 2A, B). All the muscular rosettes are incorporated into a joint muscular system. This joint net of muscular rosettes braids the central lumen of each rootlet, which is clearly seen on the transversal cryosections of the rootlets (Fig. 2C). However, in some small rootlets (presumably growing ones) we found only a single line of muscular rosettes (Fig. 1A). The muscular origin of these structures was confirmed at ultrastructural level (Fig. 2D).

The muscular system of the interna of $S$. pilosella has the same organization as $P$. polygenea. The muscular rosettes were found in the body wall of all examined rootlets. These rosettes were connected to each other by the muscular processes and formed joint muscular system (Fig. 3A, B). Therefore, the muscular system of $S$. pilosella is similar to that of $P$. polygenea. The only difference is that the density of muscular rosettes in the interna of $S$. pilosella is a little bit higher than in $P$. polygenea (Fig. 3A, B).

\section{Discussion}

This study shows that the representatives of the family Sacculinidae have unique type of muscular system in a form of a joint net with muscular rosettes in a grid points. Such type of muscular system has never been observed in any other animal.

The muscular system in the interna of sacculinids greatly differs from that has been earlier described for a peltogastrid P. paguri (Miroliubov, 2017). We suggest that such differences could stem from the dissimilar type of interna gross morphology. The interna of the Peltogastridae is more differentiated when compared with the Sacculinidae. Representatives of $P$. paguri have the main trunk, which is the central element of the interna and side rootlets branching from it. A special stalk connects the central part of the trunk with the externa. So trophic rootlets are considered to absorb nutrients and transport them to the lumen of the main trunk. Spiral muscular system in the body wall provides peristaltic movement that transports them 

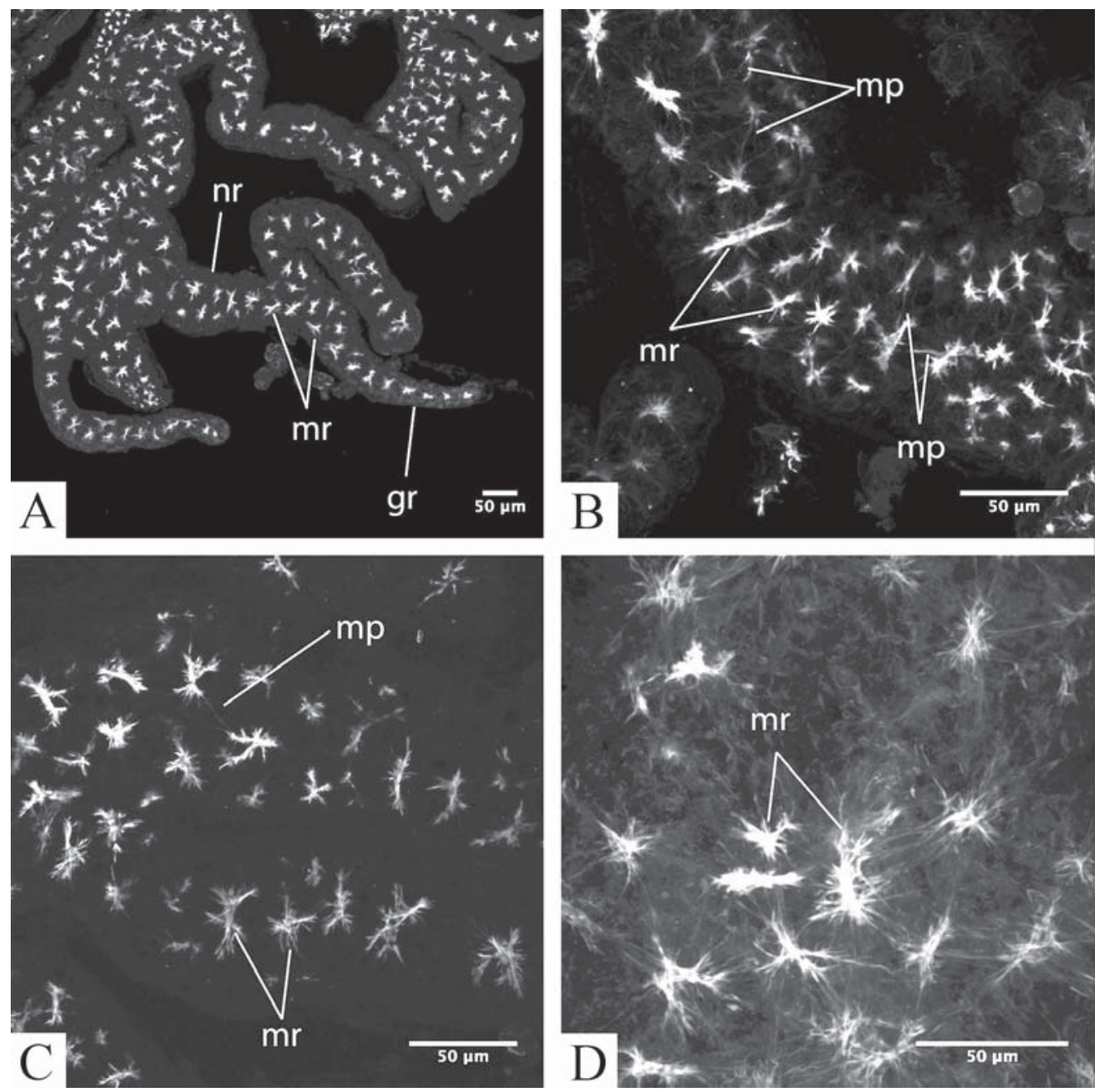

Fig. 1. Contractile muscular structures in the interna of Polyascus polygenea. Confocal Z-stack, phalloidin labeling. A - part of the interna with a wide, normal, and small growing rootlets; B — fragment of the rootlet with contractile muscular elements; $\mathrm{C}, \mathrm{D}$ - muscular rosettes.

Abbreviations: gr — growing rootlet; $\mathrm{mp}$ - muscular processes; $\mathrm{mr}$ - muscular rosette; $\mathrm{nr}$ - normal rootlet.

Рис. 1. Сократимые мышечные элементы в интерне Polyascus polygenea. Z-проекция конфокальных снимков, мечение фаллоидином. А - часть интерны с крупными, нормальными и маленькими растущими столонами; В - фрагмент столона с сократимыми мышечными элементами; C, D мышечные розетки.

Обозначения: $\mathrm{gr}$ - растущий столон; $\mathrm{mp}$ - мышечные отростки; $\mathrm{mr}$ - мышечные розетки; $\mathrm{nr}$ - нормальный столон.

along the channel system of the parasite (Miroliubov, 2017). The side branches have no contractile elements. Possibly the convectional movement of liquid in the central lumen of the main trunk also involves liquid inside side branches in moving.
In contrast to the peltogastrids the interna of sacculinids has no central elements such as main trunk. It appears as randomly ramifying rootlets (Bresciani, Høeg, 2001). At the same time the interna is quite abundant and the distance between the stalk of the externa and the tips of the 

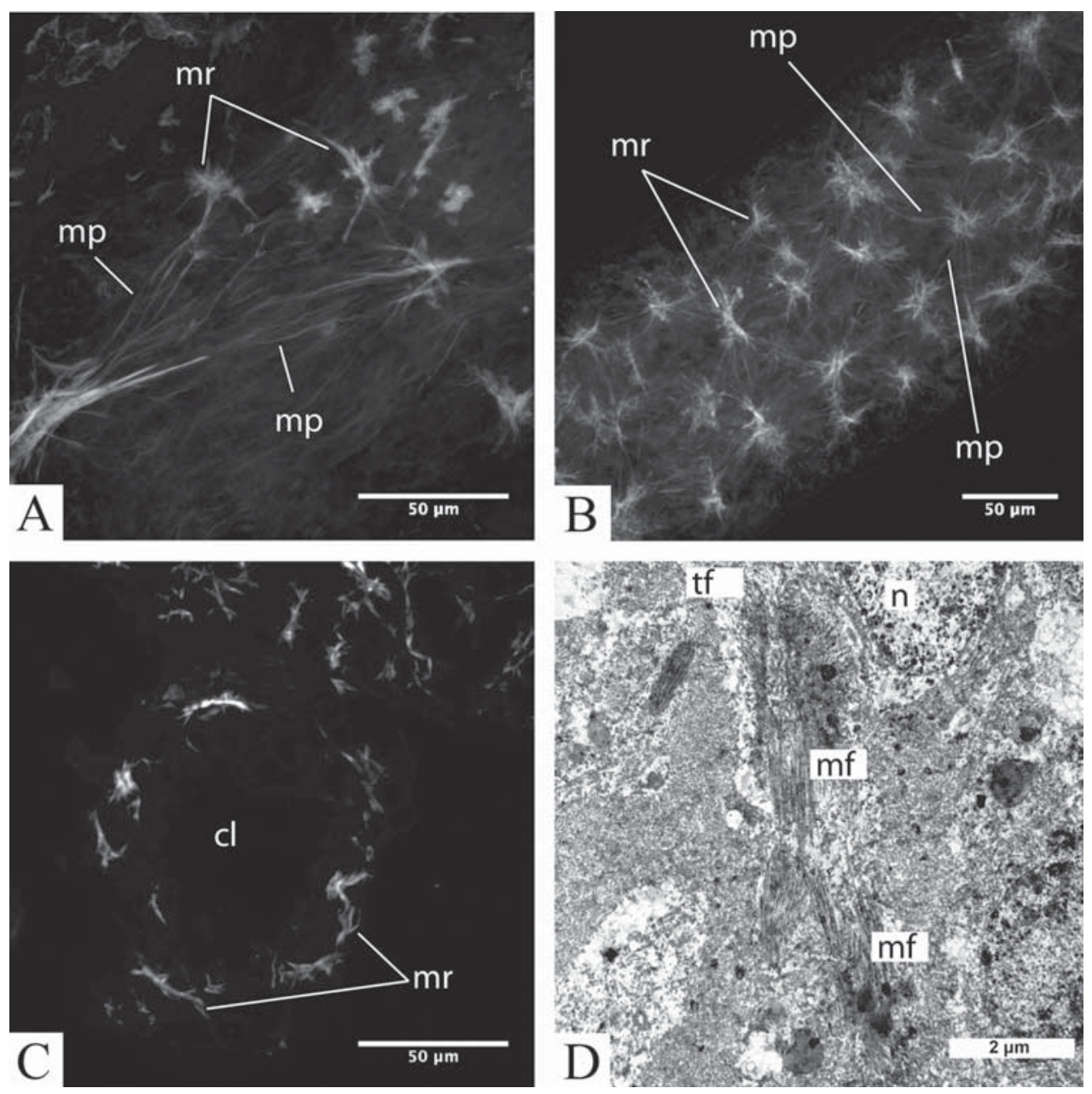

Fig. 2. Muscular rosettes in the body wall of the rootlets of Polyascus polygenea. A - muscular processes between neighboring muscular rosettes. Confocal Z-stack, phalloidin labeling; B - the fragment of the rootlet with muscular rosettes. Confocal Z-stack, phalloidin labeling; $\mathrm{C}$ - the transversal cryosection of the rootlets with muscular rosettes in the wall of the interna. Confocal Z-stack, phalloidin labeling; D muscular fiber with tonofillamets, TEM.

Abbreviations: $\mathrm{cl}$ - central lumen; $\mathrm{mf}-$ muscular fiber; $\mathrm{mp}$ - muscular processes; $\mathrm{mr}$ - muscular rosette; $\mathrm{tf}-$ tonofillamets.

Рис. 2. Мышечные розетки в стенке столонов Polyascus polygenea. A - мышечные волокна соединяющие соседние мышечные розетки. Z-проекция конфокальных снимков, мечение фаллоидином; B - фрагмент столона с мышечными розетками. Z-проекция конфокальных снимков, мечение фаллоидином; C - поперечный криосрез столона с мышечными розетками в стенке интерны. Zпроекция конфокальных снимков, мечение фаллоидином; D - мышечное волокно с тонофилламентами. ТЕМ.

Обозначения: $\mathrm{cl}$ — центральный канал; $\mathrm{mf}$ - мышечное волокно; $\mathrm{mp}$ — мышечные отростки; $\mathrm{mr}$ — мышечные розетки; tf — тонофилламенты.

rootlets can reach several centimeters. Transport via diffusion is not available for such distances. We suggest that such net-like muscular system is also necessary for the transportation of nutrients along the interna, and since there is no big central cavity, each of the rootlet has muscular fibers that braid the lumen. Unfortunately we have no data to explain how such 

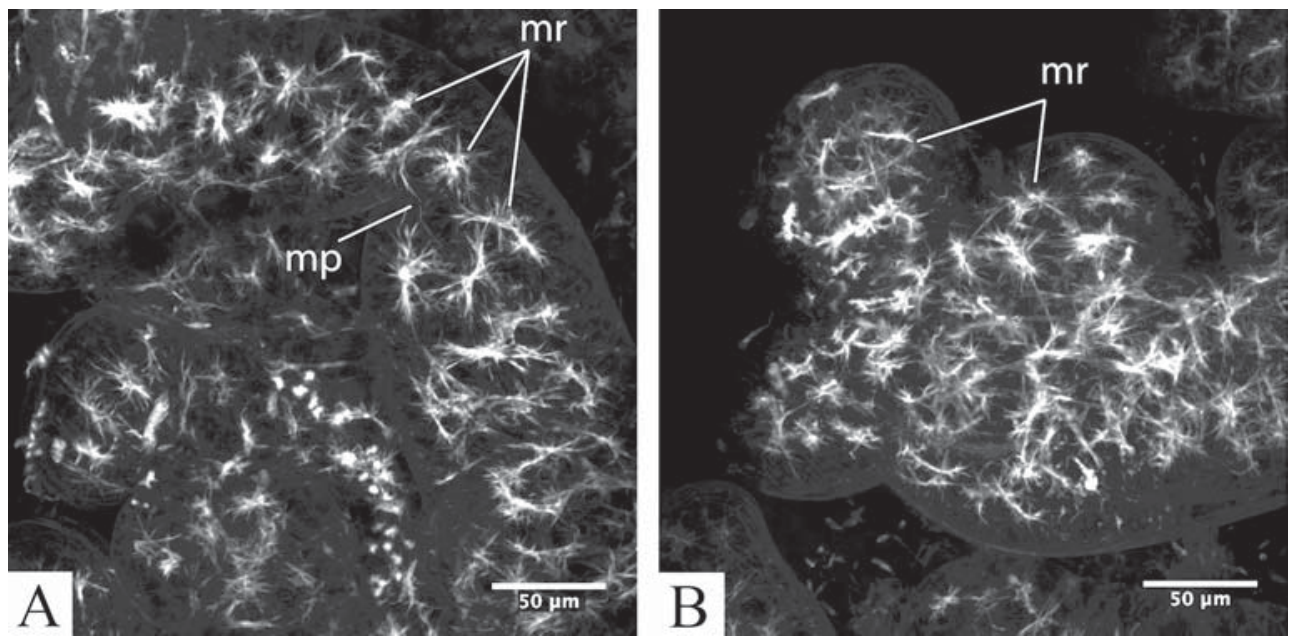

Fig. 3. Contractile muscular structures in the interna of Sacculina pilosella. Confocal Z-stack, phalloidin labeling. A-B - the rootlets of S. pilosella with muscular rosettes in the body wall.

Abbreviations: $\mathrm{mp}$ - muscular processes; $\mathrm{mr}$ - muscular rosette.

Рис. 3. Сократимые мышечные элементы в интерне Sacculina pilosella. Z-проекция конфокальных снимков, мечение фаллоидином. A-B - столоны S. pilosella с мышечными розетками а стенке тела. Обозначения: $\mathrm{mp}$ - мышечные отростки; $\mathrm{mr}$ - мышечные розетки.

muscular system functions and how it is controlled.

We observed that on the distal parts of the rootlets muscular rosettes were lying in a line. This suggests possible absence of the central lumen in young rootlets (Fig. 1A). We propose that these rootlets are the growing parts of the interna. Therefore, the muscular rosettes seem to appear next to the tip of growing rootlet. The density of muscular rosettes increases just after the expansion of the thickness of the rootlet.

It is still unclear what is the way of innervation in both of these muscular systems (peltogastrid type and sacculinid type)? Unfortunately, the nervous system associated with muscular fibers has not been found in this study nor in the previous description (Miroliubov, 2017). The nervous system of the rhizocephalans is one of the most enigmatic phenomena, as it still has never been described. We suggest that innervation of these muscles could be carried out by a range of ways. First of all, we tried to treat the interna with antibodies against different neurotransmitters, however we got no significant staining pattern. It is possible that our protocols were not appropriate enough to visualize rhizocephalan neurvous system, as they could differ from other animals by a composition of neurotransmitters. Secondly, perhaps somewhere in the interna there is a ganglion or a group of neurvous cells that provide neural signals. These impulses could spread along the whole interna, through intercellular junctions, since all muscular fibers are incorporated into the joint muscular system. Thirdly, it is possible that modified muscular cells - pacemakers could generate an impulse, or there is another origin of a signal that runs muscular contraction.

Structural differences between two types of muscular system of $P$. paguri on the one hand and $P$. polygenea and S. pilosella on another are also very interesting in context of evolution and phylogeny of the rhizocephalans. According to the phylogenetic tree, $P$. paguri has one of the most basal position in the rhizocephalan clade, while $P$. polygenea is usually located in the crown (Glenner, Hebsgaard, 2006; Pérez-Losada, 2008; Glenner, 2010). Unfortunately only three species are studied and it is early to make any conclusions about the evolution of muscu- 
lar systems among the Rhizocephala. We are unable to establish whether these two types of muscular system appeared independently or not. However, we suggest that the type of muscular system in the interna should be quite flexible and depends on the type of the interna organization. We need more data on the structure of neuromuscular systems in other species and clades of these parasitic barnacles.

\section{Acknowledgements}

We are grateful to the staff of Resource Centre "Microscopy and Microanalysis", "Chromas" and "Molecular and Cell Technologies" of the Research park of Saint-Petersburg State University. Authors also thank the divers team of the Marine biological station "Vostok" of National Scientific Center of Marine Biology, FEB RAS, for the help with collecting specimens. We would like also to acknowledge Dr. Anna Zalota for the help with text editing. This study was supported by grant No. 18-34-00727 from the Russian Foundation for Basic Research.

\section{References}

Alvarez F., Alcaraz G., Robles R. 2002. Osmoregulatory disturbances induced by the parasitic barnacle Loxothylacus texanus (Rhizocephala) in the crab Callinectes rathbunae (Portunidae) // J. Exp. Mar. Biol. Ecol. Vol.278. P.135-140.

Alvarez F., Hinesb A.H., Reaka-Kudla M.L. 1995. The effects of parasitism by the barnacle Loxothylacus panopaei (Gissler) (Cirripedia: Rhizocephala) on growth and survival of the host crab Rhithropanopeus harrisii (Gould) (Brachyura: Xanthidae) // J. Exp. Mar. Biol. Ecol. Vol.192. P.221-232.

Belgrad B.A., Griffen B.D. 2015. Rhizocephalan infection modifies host food consumption by reducing host activity levels // J. Exp. Mar. Biol. Ecol. Vol.466. P.70-75.

Bocquet-Vedrine J., Chassard-Bouchaud C., Hubert M. 1977. Ultrastructure et fonction d'absorbtion de tegument des racines de la Sacculine (Crustace Cirripe"de parasite) // Biol. Cell. Vol.30. P.165-170.

Bortolini J.L., Alvarez F. 2008. Hepatopancreas alteration of the blue crab Callinectes sapidus by the rhizocephalan barnacle Loxothylacus texanus // J. Invert. Pathol. Vol.99. P.354-356.

Bresciani J., Høeg J.T. 2001. Comparative ultrastructure of the root system in rhizocephalan barnacles (Crustacea: Cirripedia: Rhizocephala) // J. Morphol. Vol.249. P.9-42.
Collis S.A., Walker G. 1994. The morphology of the naupliar stages of Sacculina carcini (Crustacea: Cirripedia: Rhizocephala) // Acta Zool. Vol.75. No.4. P.297-303.

Glenner H. 2001. Cypris metamorphosis, injection and earliest internal development of the rhizocephalan Loxothylacus panopaei (Gissler) Crustacea: Cirripedia: Rhizocephala: Sacculinidae// J. Morphol. Vol.249. P.43-75.

Glenner H., Hebsgaard M.B. 2006. Phylogeny and evolution of life history strategies of the parasitic barnacles (Crustacea, Cirripedia, Rhizocephala) // Mol. Phylogenet. Evol. Vol.41. No.3. P.528-538.

Glenner H., Høeg J.T. 1995. A new motile, multicellular stage involved in host invasion by parasitic barnacles (Rhizocephala) // Nature. Vol.377. No.14 P.147-149.

Glenner H., Høeg J.T., O’Brien J.J., Sherman T.D. 2000. Invasive vermigon stage in the parasitic barnacles Loxothylacus texanus and L. panopaei (Sacculinidae): closing of the rhizocephalan life-cycle // Mar. Biol. Vol.136. P.249-257.

Graham W. 2001. Introduction to the Rhizocephala (Crustacea: Cirripedia) // J. Morphol. Vol.249. P.1-8.

Høeg J.T. 1995. The biology and life cycle of Rhizocephala (Cirripedia) // J. Mar. Biol. Ass. U.K. Vol.75. P.517-550.

Høeg J.T., Glenner H., Shields J. 2005. Cirripedia thoracica and Rhizocephala (barnacles) // K. Rohde (ed.). Marine Parasitology. CABI Publishing, Wall- ingford U.K. \& CSIRO Publishing, Collingwood, Victoria, Australia, P.154-165.

Høeg J.T., Maruzzo D., Okano K., Glenner H., Benny K.K. Chan. 2012. Metamorphosis in balanomorphan, pedunculated, and parasitic barnacles: A video-based analysis // Integr. Comp. Biol. Vol.52. No.3. P.337347.

Høeg J.T., Rybakov A.V. 2007. Cypris larvae in Polysaccus mediterraneus and Mycetomorpha vancouverensis: their importance in analyzing the phylogeny and sexual evolution of parasitic barnacles (Crustacea: Cirripedia: Rhizocephala)//Israel J. Ecol. Evol. Vol.53. P.9-31.

Isaeva V.V., Shukalyuk A.I., Trofimova A.V., Korn O.M., Rybakov A.V. 2001. The structure of colonial interna in Sacculina polygenea (Crustacea: Cirripedia: Rhizocephala) // Crust. Res. Vol.30. P.133-146.

Korn O.M., Rybakov A.V. 2001. Larval development?in the rhizocephalan barnacle Sacculina pilosella // Russ. J. Mar. Biol. Vol.27. No.3. P.177-179.

Korn O.M., Rybakov A.V., Kashenko S.D. 2000. Larval development of the rhizocephalan Sacculina polygenea (Crustacea: Cirripedia) // Russ. J. Mar. Biol. Vol.26. No.5. P.373-377.

Kristensen T., Nielsen A.I., Jørgensen A.I., Mouritsen K.N., Glenner H., Christensen J.T., Lützen J., Høeg J. T. 2012. The selective advantage of host feminization: a case study of the green crab Carcinus maenas and the parasitic barnacle Sacculina carcini // Mar. Biol. Vol.159. P.2015-2023.

Lützen J. 2002. Interna structure and nucleus formation in Sacculina polygenea (Crustacea: Cirripedia: Rhizocephala: Sacculinidae) // Crust. Res. Vol.31. P.39-46. 
Lützen J., Jensen K.H., Glenner H. 2018. Life history of Sacculina carcini Thompson, 1836 (Cirripedia: Rhizocephala: Sacculinidae) and the intermoult cycle of its host, the shore crab Carcinus maenas (Linnaeus, 1758) (Decapoda: Brachyura: Carcinidae) // J. Crustac. Biol. Vol.38. No.4. P.413-419.

Lützen J., Takahashi T. 1996. Morphology and biology of Polysaccus japonicus (Crustacea, Rhizocephala, Akentrogonida, Polysaccidae, fam. n.), a parasite of the ghost-shrimp Callianassa japonica // Zool. Scr. Vol. 25. No.2. P.171-181.

Miroliubov A.A. 2017. Muscular system in interna of Peltogaster paguri (Rhizocephala: Peltogastridae) // Arthropod Struct. Dev. Vol.46. No.2. P.230-235.

Nagler C., Hornig M.K., Haug J.T., Noever C., Høeg J.T., Glenner H. 2017. The bigger, the better? Volume measurements of parasites and hosts: Parasitic barnacles (Cirripedia, Rhizocephala) and their decapod hosts // PLoS ONE Vol.12. No7: e0179958.

Pérez-Losada M., Harp M., Høeg J.T., Achituv Y., Jones D., Watanabe H., Crandall K.A. 2008. The tempo and mode of barnacle evolution // Mol. Phylogenet. Evol. Vol.46. No.1. P.328-346.
Pérez-Losada M., Høeg J.T., Kolbasov G.A., Crandall K.A. 2002. Reanalysis of the relationships among the Cirripedia and the Ascothoracida and the phylogenetic position of Facetotecta (Maxilopoda: Thecostraca) using 18S rDNA Sequences // J. Crustac. Biol. Vol.22. No.3. P.661-669.

Pérez-Miguel M., Drake P., Cuesta J.A. 2017. Experimental predatory behavior of the stone crab Eriphia verrucosa (Forskål, 1775) (Decapoda, Brachyura, Eriphiidae) // Nauplius. Vol.25.

Shukalyuk A I. 2002. Organization of interna in Sacculina polygenea (Crustacea: Rhizocephala) // Russ. J. Mar. Biol. Vol.28. No.5. P.329-335.

Shukalyuk A.I., Baiborodin S.I., Isaeva V.V. 2001. Organization of the interna of the rhizocephalan barnacle Peltogasterella gracilis // Russ. J. Mar. Biol. Vol.27. No.2. P.113-115.

Zacher L.S., Horstmann L., Hardy S.M. 2018. A fieldbased study of metabolites in sacculinized king crabs Paralithodes camtschaticus (Tilesius, 1815) and Lithodes aequispinus Benedict, 1895 (Decapoda: Anomura: Lithodidae) // J. Crustac. Biol. Vol.38. No.6. P.794-803.

Responsible editor E.N. Temereva 